\title{
Can cocoa agroforestry restore degraded soil structure following conversion from forest to agricultural use?
}

\author{
Danny Dwi Saputra (D) Rika Ratna Sari - Kurniatun Hairiah · James M. Roshetko • \\ Didik Suprayogo $\cdot$ Meine van Noordwijk
}

Received: 12 February 2020/ Accepted: 18 September 2020/Published online: 29 September 2020

(C) The Author(s) 2020

\begin{abstract}
Alternating degradation and restoration phases of soil quality, as is common in crop-fallow systems, can be avoided if the restorative elements of trees and forests can be integrated into productive agroforestry systems. However, evidence for the hypothesis of 'internal restoration' in agroforestry is patchy and the effectiveness may depend on local context. We investigated to what extent cocoa (Theobroma cacao, L.) agroforestry can recover soil structure and infiltration in comparison to monoculture systems across the Konaweha Watershed, Southeast Sulawesi. We compared soil organic carbon, fine root length and weight, soil aggregate stability, macroporosity and infiltration from three soil layers at five land use systems: i.e. degraded forests, 9-14 years old of complex-cocoa agroforestry, simple-cocoa agroforestry, monoculture cocoa and 1-4 years old annual
\end{abstract}

D. D. Saputra $(\bowtie) \cdot$ R. R. Sari · M. van Noordwijk Plant Production Systems, Department of Plant Sciences, Wageningen University and Research, P.O. Box 430, 6700 AK Wageningen, The Netherlands

e-mail: dannydwi.saputra@wur.nl;

danny_saputra@ub.ac.id

D. D. Saputra - R. R. Sari · K. Hairiah · D. Suprayogo Department of Soil Science, Faculty of Agriculture, Brawijaya University, Jalan Veteran, Malang 65145, Indonesia

J. M. Roshetko $\cdot$ M. van Noordwijk

The World Agroforestry Centre (ICRAF) Southeast Asia,

Bogor, Indonesia food crops, all with three replications. In general, roots were concentrated in the upper $40 \mathrm{~cm}$ of soil depth, contained of $70 \%$ and $86 \%$ of total fine root length and weight. Compared to simple agroforestry and cocoa monoculture, complex agroforestry had greater root length and weight in the topsoil, even though it attained only half the values found in degraded forests. Higher root density was positively correlated to soil organic carbon. In upper soil layers, complex agroforestry had slightly higher soil aggregate stability compared to other agricultural systems. However, no significant difference was found in deeper layers. Complex agroforestry had higher soil macroporosity than other agricultural systems, but not sufficient to mimic forests. Degraded forests had two times faster steady-state soil infiltration than agricultural systems tested $\left(13.2 \mathrm{~cm} \mathrm{~h}^{-1}\right.$ and $6 \mathrm{~cm} \mathrm{~h}^{-1}$, respectively), relevant during peak rainfall events. Compared to other agricultural systems, complex agroforestry improves soil structure of degraded soil resulting from forest conversion. However, a considerable gap remains with forest soil conditions.

Keywords Soil organic matter · Root density · Aggregate stability · Macroporosity · Infiltration
Abbreviations
CAF Complex cocoa agroforestry
$\mathrm{CM}$ Cocoa monoculture
CR Annual food crops 
DF Degraded forests

$\mathrm{D}_{\mathrm{rv}} \quad$ Dry weight of fine roots per volume of soil

$\mathrm{L}_{\mathrm{rv}} \quad$ Length of fine roots per volume of soil

LUS Land use systems

MWD Mean weight diameter

SAF Simple cocoa agroforestry

SOC Soil organic carbon

\section{Introduction}

Once the litter layer and protective canopy cover of natural vegetation is removed by clearing land for agriculture, tropical soils are exposed to sunshine and harsher micro climatic conditions such as higher temperatures, lower relative humidity and lower soil moisture due to greater insolation (Hoffmann 2003). These unfavourable conditions combined with changes in litter quality and quantity allow the rapid disappearance of any new surface litter. Litter with high quality (low $\mathrm{C} / \mathrm{N}$ or lignin/ $\mathrm{N}$ ) has faster decomposition rates compared to low litter quality (high $\mathrm{C} / \mathrm{N}$ or lignin/N) (Chae et al. 2019). Faster litter decomposition combined with a lower root density and turnover could reduce the organic matter (Hairiah et al. 2006), and lead to anthropogenic soil degradation (Lal 2015). The decline of soil organic matter is often linked to several soil functions such as presence and activity of soil biota, soil structure, water and nutrient availability (Fig. 1). Soil organic matter is also considered to be a key characteristic in judging soil

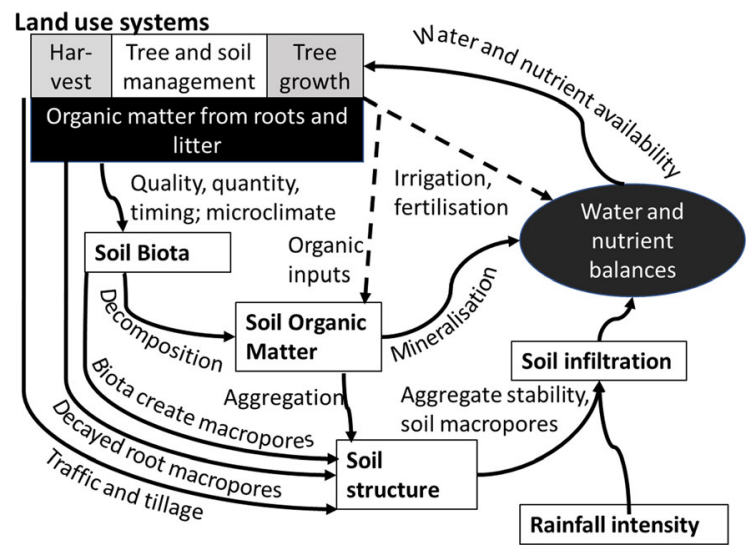

Fig. 1 Conceptual diagram of soil degradation and restoration caused by different land use systems quality (Martinez-Salgado et al. 2010) and land use system sustainability (Lal 2015).

In swidden-fallow systems, as the origin of nearly all agriculture, an alternation of crop production, resulting in soil degradation, and soil recovery in a fallow vegetation of lower direct use value is common (Sanchez 2019). However, such alternating net degradation and restoration phases of soil quality can be avoided if the restorative elements of forests can be integrated into productive agroforestry systems (Pinho et al. 2012; van Noordwijk 2019). Tree diversity can ensure an appropriate range of rooting patterns for better soil exploration, interactions with soil structure and biota, and litter input to provide such functions (Ordonez et al. 2014; van Noordwijk et al. 2015). Nevertheless, the hypothesis on 'internal restoration' in agroforestry has not been widely accepted yet, as the evidence is patchy and remains unclear (Barreto et al. 2010; Norgrove and Beck 2016; Schroth et al. 2001). Effectiveness may depend on local context and circumstances (Arévalo-Hernández et al. 2017; Zamora and Udawatta 2016).

Cocoa (Theobroma cacao L.), as a neotropical understorey rainforest species, initially planted in the shade of remnant forest trees (Rice and Grismer 2010) and subsequently planted with non-native trees such as nitrogen-fixing legume (Rajab et al. 2018) as well as timber and fruit trees in the form of agroforestry. Nevertheless, with progress in selection of 'full-sun' genotypes (Obeng and Aguilar 2015) due to the fear of yield losses caused by competition between crop and shade trees (Tscharntke et al. 2011), cocoa is one of the tree crops that mixed agroforestry systems are being replaced by intensive monocultures as a land sparing technique (Vaast and Somarriba 2014). However, negative effects on soil conditions, risks of diseases and greater vulnerability to climate extremes may all point towards a return to partially shaded, mixed agroforestry systems as the more sustainable choice. Therefore, more evidence is needed to judge both the urgency (soil quality decline under monocultures) and opportunities (improvement of soil conditions by inclusion of other trees) in cocoa production.

During its top production year of 2010, Indonesia was the worlds' second cocoa producing country, behind the Ivory Coast. However, while production in other countries continued to increase, Indonesian production has since declined, with national data for 2010 and 2017 indicating 0.844 and $0.530 \mathrm{M}$ tonnes 
per year, respectively (FAO 2017). The declines in cocoa productivity, quality and consistency in Sulawesi, as the main cocoa producer area in Indonesia, are due to several interacting factors (Neilson 2007), including the infestation by pest and diseases, low quality of planting materials, insufficient post-harvest handling and the decline of soil fertility.

The main objective of this study was to investigate whether agroforestry systems can restore degraded soil structure relative to monoculture systems. A comparative study at the plot level was carried out in Konaweha Watershed, where different cocoa managements (agroforestry and monoculture), crop monoculture and remnant forests were presented under similar climatic and soil condition. We investigated the vertical distribution of fine root $(<2 \mathrm{~mm})$, soil organic carbon, soil aggregate stability and soil macroporosity as well as soil infiltration on the five different land use systems. We aimed to test the hypotheses that (1) vertical distribution of fine root increases with increasing tree diversity through agroforestry, (2) increasing fine root distribution results in higher soil organic carbon, as fine roots are one of the sources of soil organic matter in the soil after decomposed. We further hypothesized that (3) the higher root distribution and soil organic carbon due to more complex land use systems results in stronger soil aggregate stability and higher proportion of soil macropore. Finally, we expected that (4) soil infiltration is higher in complex land use systems (degraded forests and agroforestry) compared to monoculture cocoa and crop systems. This study complements the analysis by Wartenberg et al. (2017) on changes in soil microbial activity and soil fertility, and Sari et al. (2020) on tree diversity and carbon stocks in the same range of land use systems.

\section{Materials and methods}

Description of the study area

The study was conducted in the Konaweha Watershed, located in Konawe district, Southeast Sulawesi, Indonesia. The average annual precipitation is 1500-1900 mm, with the daily temperature 24-31 ${ }^{\circ} \mathrm{C}$ (a detailed description of the study area is provided in Sari et al. (2020)). Based on the map provided by FAO-UNESCO (1979), soil in the mountainous area is dominated by weathered orthic acrisols, while in the valley and floodplain is dominated by dystric fluvisols. On the basis of land use change analysis, three villages including Asinua Jaya, Wonuahoa and Lawonua were selected to represent the whole watersheds. Villages were selected for their opportunity to compare the desired range of land uses and otherwise sample the existing geographical and ecological variation in the catchment.

All field activities such as identification and characterisation of plots, soil and root sampling, and soil infiltration measurement were conducted from March to May 2014. The measurements were made in five land use systems with three replications (total of 15 plots). The five selected land use systems (LUS) are as follows: (1) degraded forests (DF) as a control, (2) complex agroforestry (CAF), multistrata cocoa with fruit and timber trees as well as nitrogen fixing shade trees (Gliricidia sepium), (3) simple agroforestry (SAF), cocoa with mainly Gliricidia sepium as a shading tree and/or fruit trees, (4) full sun "monoculture" cocoa (CM) and (5) annual food crops (CR) of maize (Zea mays), groundnut (Arachis hypogea), and patchouli (Pogostemon cablin). Each cocoa-based system was represented by three different farmer's plots, with plots of each cocoa treatment located in each of three villages (Table 1). Degraded forest and annual food crop plots were also located in those villages. As a control treatment, we chose degraded forests instead of natural forests due to plot accessibility. In this study we used the FAO term defining the forest degradation as: "changes within the forest which negatively affect the structure or function of the stand or site, and thereby lower capacity to supply products and/or services" (Schoene et al. 2007). In this particular region, degraded forests are relatively open forests mainly resulted from human activities such as overexploitation of forest trees for timber and fuelwood. Degradation results in a reduction in biomass, and changes in tree species composition, structure and productivity compared to natural forest type expected on this site.

As an operational definition for simple agroforestry, we used a relative basal area $<80 \%$, with five or less other tree species per plot. Whereas gardens with relative cocoa basal area $<80 \%$, with more than five tree species were categorized as complex agroforestry. The gardens with a relative cocoa basal area $>80 \%$ were defined as cocoa 
Table 1 The general characteristics of degraded forests, cacao systems and annual food crop

\begin{tabular}{|c|c|c|c|c|c|c|c|}
\hline Land use systems & Location $^{\mathrm{a}}$ & $\begin{array}{l}\text { Plot } \\
\text { age } \\
\text { (years) }\end{array}$ & $\begin{array}{l}\text { Tree Density, } \\
\text { Trees } \text { ha }^{-1 \text { b }}\end{array}$ & $\begin{array}{l}\text { Number of } \\
\text { tree } \\
\text { species }^{b}\end{array}$ & $\begin{array}{l}\text { Shannon } \\
\text { index } \\
(H)^{\mathrm{b}}\end{array}$ & $\begin{array}{l}\text { Dominant/Codominant tree } \\
\text { species }^{b}\end{array}$ & Soil texture \\
\hline $\begin{array}{l}\text { Degraded Forests } \\
\text { (DF) }\end{array}$ & $1,2,3$ & - & 1275 & 28 & 2.36 & $\begin{array}{l}\text { Metrosideros petiolata, } \\
\text { Homalium foetidum }\end{array}$ & $\begin{array}{l}\text { Silty clay- } \\
\text { silty clay } \\
\text { loam }\end{array}$ \\
\hline $\begin{array}{l}\text { Cacao Complex } \\
\text { Agroforestry } \\
\text { (CAF) }\end{array}$ & $1,2,3$ & $9-14$ & 1317 & 18 & 0.93 & $\begin{array}{l}\text { Theobroma cacao, Durio } \\
\text { zibethinus, Lansium } \\
\text { domesticum }\end{array}$ & $\begin{array}{l}\text { Silt loam- } \\
\text { silty clay } \\
\text { loam }\end{array}$ \\
\hline $\begin{array}{l}\text { Cacao Simple } \\
\text { Agroforestry } \\
\text { (SAF) }\end{array}$ & $1,2,3$ & $9-14$ & 1267 & 4 & 0.58 & $\begin{array}{l}\text { Theobroma cacao, Gliricidia } \\
\text { sepium }\end{array}$ & $\begin{array}{l}\text { Silt loam- } \\
\text { silty clay } \\
\text { loam }\end{array}$ \\
\hline $\begin{array}{l}\text { Cocoa } \\
\text { Monoculture } \\
(\mathrm{CM})\end{array}$ & $1,2,3$ & $9-14$ & 900 & 2 & 0.24 & Theobroma cacao & $\begin{array}{l}\text { Silt loam- } \\
\text { silty clay } \\
\text { loam }\end{array}$ \\
\hline $\begin{array}{l}\text { Annual food crops } \\
\text { (CR) }\end{array}$ & $1,2,3$ & $1-4$ & - & - & - & - & Silt loam \\
\hline
\end{tabular}

${ }^{a}$ Lawonua (1), Wonuahoa (2), Asinua Jaya (3)

${ }^{\mathrm{b}}$ Sari et al. (2020)

monoculture. We calculated relative cocoa basal area based on the total tree basal area and the proportion of this area occupied by 'cocoa' trees (Sari et al. 2020). To measure research variables, we used plots of $20 \mathrm{~m} \times 20 \mathrm{~m}$ with a minimum age of cocoa 9 to 14 years and 1 to 4 years old of annual crops. All LUS were replicated three times (fifteen plots in total). All the plots were included in the scope of the 'Agroforestry and Forestry in Sulawesi' (AgFor) project of the World Agroforestry Centre (ICRAF).

Soil sampling and preparation

We collected disturbed and undisturbed soil samples from three soil layers of soil profile. The soil layer depth in all plots averaged $0-21 \mathrm{~cm}$ for the first layer, $21-51 \mathrm{~cm}$ for the second layer and $52-90 \mathrm{~cm}$ for the third layer. We prefer to use layer boundary, instead of exact soil depth intervals (i.e. 0-10, 10-20, 20-30, and so on) to efficiently access the impact of root distribution on soil organic matter and soil macropore and aggregate stability throughout the soil profile. This approach is based on studies which report that infiltration process is greatly influenced by the existence of soil layers with low permeability that can appear in the deeper of soil profile (Chaplot et al. 2011;
Mahapatra et al. 2020; Saito et al. 2016), and are not necessarily correlated to the topsoil characteristics.

In each LUS, we collected two sample points within $400 \mathrm{~m}^{2}$ plot area. Soil samples from those sample points were mixed to create soil composite. In total, we collected 45 composite soil samples (five LUS with three soil layers and three replications). Composite samples were air-dried at room temperature, grounded and sieved at $2 \mathrm{~mm}$ and was analysed in Soil Science Laboratory of Brawijaya University. Disturbed soil samples were used to measure soil organic carbon (SOC, \%) through Walkley and Black method (Anderson and Ingram 1994). Undisturbed soil samples were used to measure soil aggregate stability through wet-sieving methods and were represented as Mean Weight Diameter (MWD, mm) (Carrizo et al. 2015).

Trenching methods for fine root density measurement

Fine root samples were collected by using the 'root trenching' method (Suprayogo et al. 2004). Soil pits of $1 \mathrm{~m} \times 1 \mathrm{~m} \times 1 \mathrm{~m}$ were dug, with crosscuts within blocks of $20 \mathrm{~cm} \times 10 \mathrm{~cm} \times 10 \mathrm{~cm}$. To separate root samples from the soil blocks, we placed soil blocks on two sieves, a $2 \mathrm{~mm}$ mesh size at top and a $0.5 \mathrm{~mm}$ mesh size at the bottom and then flushed the sample 
with water. The root samples remained between those two sieves was then separated from litter and dead decaying roots by handpicking. Total root length per volume of soil $\left(\mathrm{L}_{\mathrm{rv}}, \mathrm{cm} \mathrm{cm}^{-3}\right)$ and dried root weight per volume of soil $\left(\mathrm{D}_{\mathrm{rv}}, \mathrm{g} \mathrm{cm}^{-3}\right)$ were measured by using 'line interception' method of Tennant (van Noordwijk et al. 1997) (Fig. 2).

Mapping method for soil macroporosity quantification

Surface connected soil macroporosity was measured based on the infiltration pattern of methylene blue liquid. The methylene blue solution $\left(0.35 \mathrm{~g} \mathrm{l}^{-1}\right.$ of water) was applied over a soil surface area of $1 \mathrm{~m} \mathrm{x}$ $0.5 \mathrm{~m}$ and then allowed to infiltrate overnight. The distributions of methylene blue that appeared on soil profiles (macropore) were traced on plastic sheets for vertical sequence of the soil profiles (Suprayogo et al. 2004). These macroporosity maps were scanned and the total stained area was calculated by using Adobe Portable Photoshop 7.0 program (Fig. 3). Relative area stained was then interpreted as the fraction of surface connected soil macropore within the total soil volume (Hairiah et al. 2006).
Soil infiltration

Infiltration rate was measured by using a single ring infiltrometer (Sahin et al. 2016). The ring infiltrometer was inserted $15 \mathrm{~cm}$ into the soil and filled with water, after which the speed of water infiltration was measured until the infiltration rate reached a constant value (approximately $2-3 \mathrm{~h}$ ). The infiltration rate was expressed in terms of the volume of water per ground surface and per unit of time $\left(\mathrm{cm} \mathrm{h}^{-1}\right)$. Infiltration rate was determined from three measurement points for each plot (total of 45 measurements in all plots). Steady state infiltrability was afterward estimated by means of curve fitting to Horton's equation using SigmaPlot 2001 v7 software.

\section{Statistical analysis}

To evaluate the effect of different LUS, soil depth and their interaction with various research parameters, we used the general analysis of variance (ANOVA) of Genstat Sixteenth Edition (VSN International Ltd, United Kingdom). An exceptional was the soil infiltration analysis, which was measured only at the soil surface, and therefore the model analysis included only the fixed effect of LUS. Statistical differences were declared significant at $\alpha=0.05$ level. When an

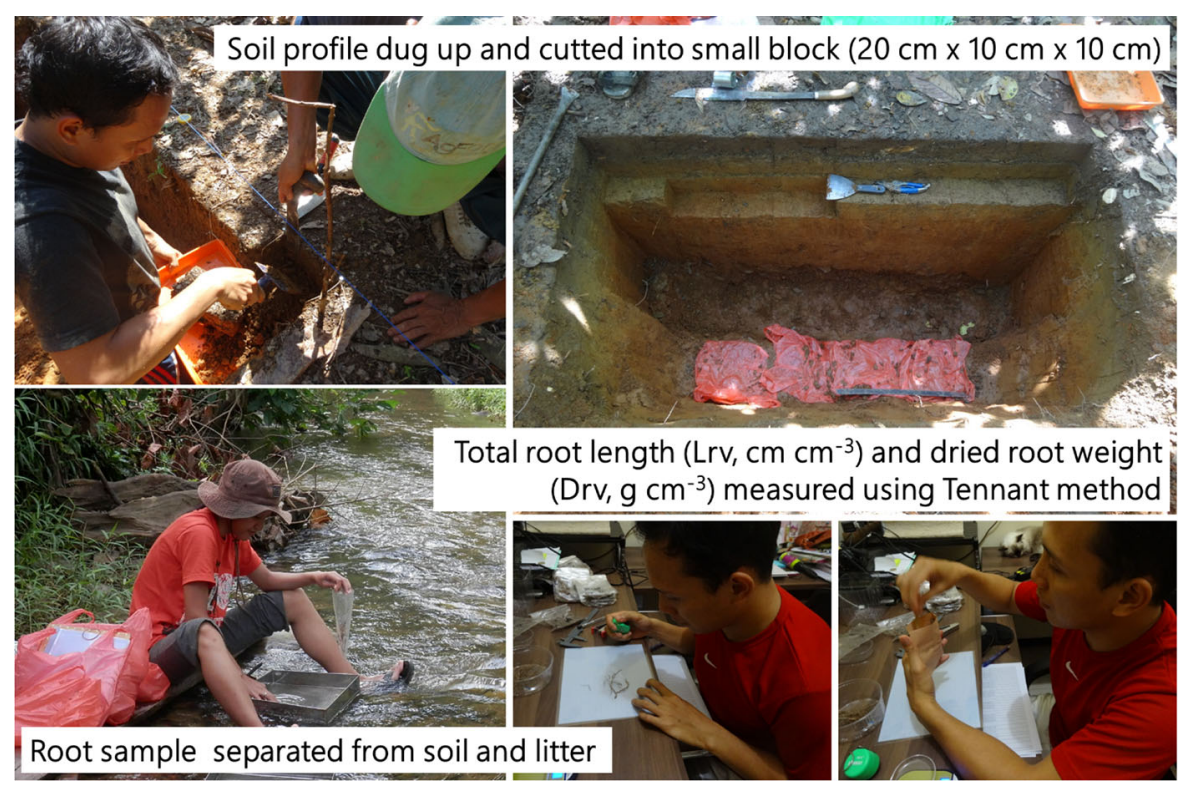

Fig. 2 Fine root sampling procedure using the 'root trenching' method; measuring dried root weight $\left(\mathrm{D}_{\mathrm{rv}}\right)$ and total root length $\left(\mathrm{L}_{\mathrm{rv}}\right)$ per volume of soil using 'line interception' method 


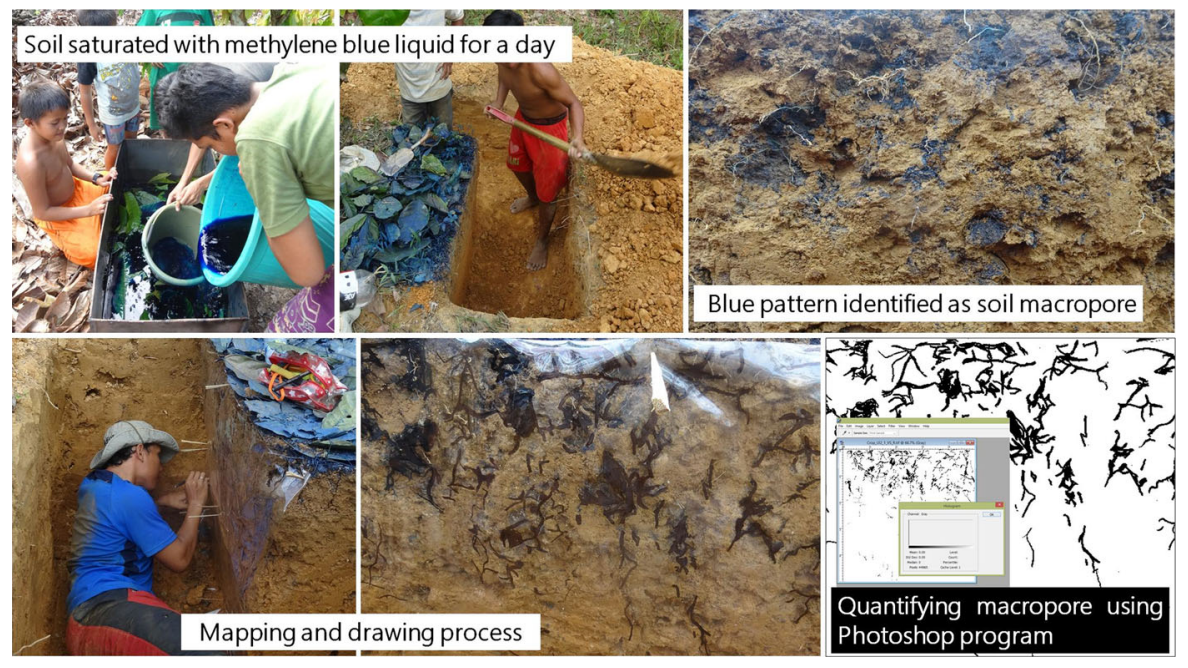

Fig. 3 Surface connected soil macroporosity quantified based on infiltration pattern of methylene blue dye

ANOVA test rejected the null hypothesis of homogeneity, the mean parameters values of the various LUS in every soil depth/layer were compared according to the Fisher's Protected LSD $(p<0.05)$. The boxplots were constructed by using 'geom_boxplot' function from 'ggplots2' package in R. To explore the relation between roots and soil characteristics, we performed stepwise regression routines using linear model. Model were fitted using ' $1 \mathrm{~m}$ ' function from 'stats' package in R.

\section{Results}

Fine root density

Overall, more than $70 \%$ of the total root length $\left(\mathrm{L}_{\mathrm{rv}}\right)$ and $86 \%$ of root dry weight $\left(\mathrm{D}_{\mathrm{rv}}\right)$ were concentrated in the upper $40 \mathrm{~cm}$ of the soil (Fig. 4a, b). We found a significant difference in $\mathrm{L}_{\mathrm{rv}}$ between LUS and soil depth, but not with the interaction between LUS and soil depth (Table 2). The large variation of $\mathrm{L}_{\mathrm{rv}}$ values found in the first $10 \mathrm{~cm}$ of soil did not reveal statistically significant differences between LUS. At a depth of 10-20 cm, degraded forests had the highest $\mathrm{L}_{\mathrm{rv}}$, followed by complex agroforestry, annual crop field, simple agroforestry, and the lowest is in cocoa monoculture. At a soil depth of $20-80 \mathrm{~cm}$, there was no significant difference between the four agricultural systems, while at a depth of 60-70 cm, we observed that cocoa monoculture had a $61 \%$ higher $\mathrm{L}_{\mathrm{rv}}$ compared to other agricultural land use systems, even though degraded forests had the highest value overall.

Similarly, results for root length, $\mathrm{D}_{\mathrm{rv}}$ differed significantly between LUS, soil depth and the interaction between LUS and soil depth (Table 2). The average $D_{\mathrm{rv}}$ in the upper $0-40 \mathrm{~cm}$ of degraded forests was 4 times higher than in agricultural systems. Meanwhile, among agricultural systems, complex agroforestry had the highest $\mathrm{D}_{\mathrm{rv}}$, followed by annual crop fields, simple agroforestry and cocoa monoculture. At a depth of 60-70 cm, cocoa monoculture had a $\mathrm{D}_{\mathrm{rv}}$ that was equivalent to that in degraded forests and five times higher than that of other agricultural systems. $D_{r v}$ was higher in cocoa monoculture than in other agricultural systems below a depth of $40 \mathrm{~cm}$. By combining root density and Shannon-Wiener index $\left(H^{\prime}\right)$ from Sari et al. (2020), we found a positive correlation among those parameters (Fig. 5).

Soil organic carbon and its correlation to root density

The average of SOC concentration in the topsoil was $1.1 \%$ across land use systems, and this number decreased significantly by a third and a half for the second and third soil layer, respectively. However, there were no statistical differences in SOC between LUS and the interaction between LUS and soil layer (Fig. 6, Table 2). We found a noticeable improvement of SOC in the simple agroforestry systems at all soil layers. Meanwhile, in complex agroforestry systems, 


\section{Soil depth, $\mathrm{cm}$}

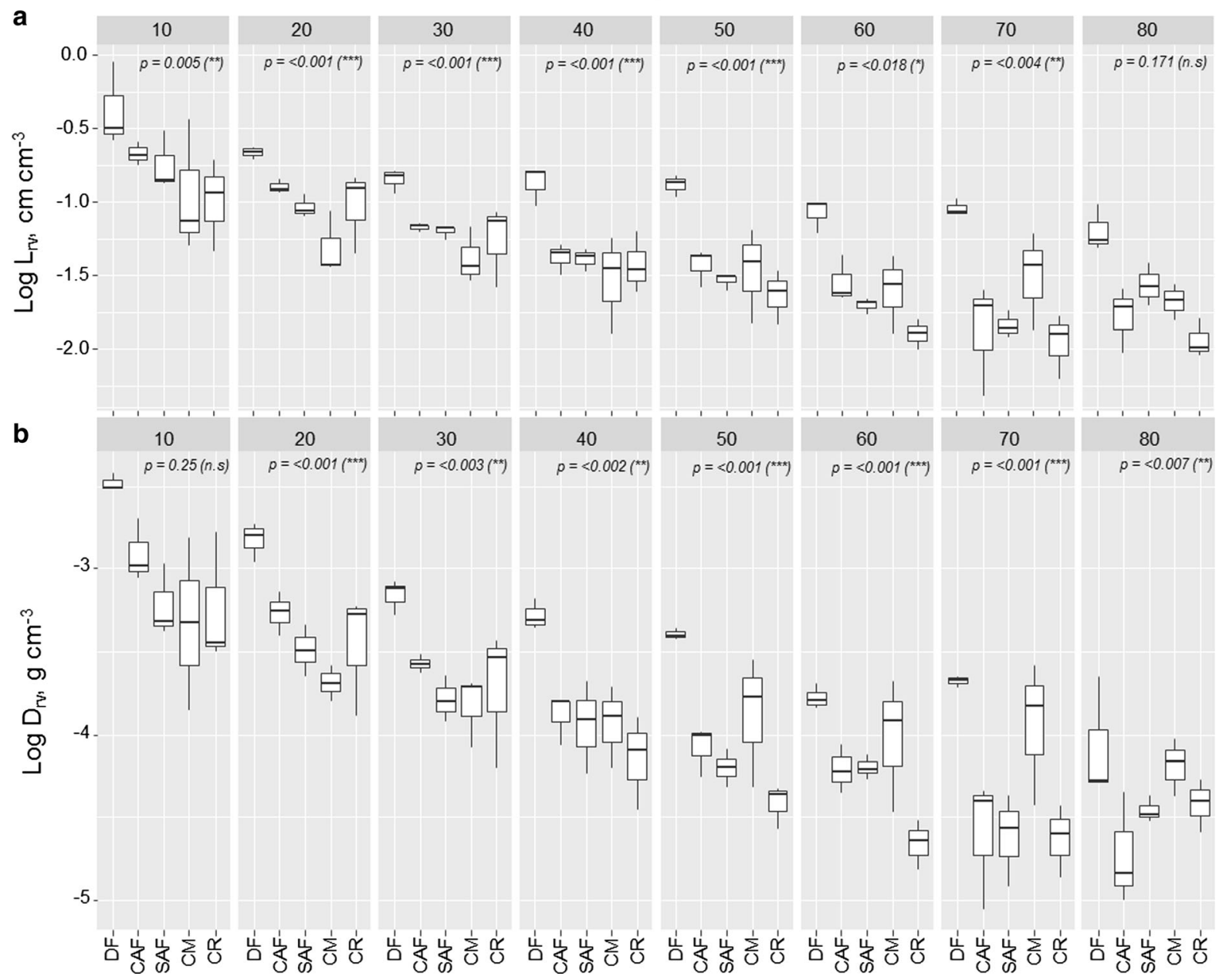

Fig. $4 \log \mathrm{L}_{\mathrm{rv}}$ (a) and $\log \mathrm{D}_{\mathrm{rv}}$ (b) boxplot distribution across degraded forest (DF), complex agroforestry (CAF), simple agroforestry (SAF), cocoa monoculture (CM) and annual crop (CR) systems

SOC was only improved in topsoil layer. We further observed a positive correlation between $\mathrm{SOC}$ and $\mathrm{L}_{\mathrm{rv}}$ and $\mathrm{D}_{\mathrm{rv}}$ (Fig. 8a, b).

Soil aggregate stability and macroporosity and its correlation to soil organic carbon

Overall, the MWD of aggregates in the topsoil layer was 59\% higher than that in the second and third soil layers (Table 2). Differences of MWD across all land use systems were statistically significant only in the topsoil layer. MWD in degraded forests was $31 \%$ to $52 \%$ higher than that of annual crop fields, cocoa monoculture, simple agroforestry and complex agroforestry (Fig. 7a).
We found a significant different on soil macroporosity between LUS, soil layers and the interaction between LUS and soil layers (Table 2). The average of surface connected soil macroporosity was $80 \%$ higher in the topsoil $(14.5 \%)$ than in the lowest soil layer (3.2\%). Differences in plot management had a significant effect on soil macroporosity in the first and third soil layer. In the topsoil, degraded forests had a $32 \%$, $54 \%, 66 \%$ and $67 \%$ higher soil macroporosity than what were found in complex agroforestry, annual crop fields and cocoa monoculture and simple agroforestry, respectively (Fig. 7b). Meanwhile in the third soil layer, complex agroforestry had a higher macroporosity compared to other agricultural systems, and even equal to degraded forests. We found that the increase 
Table 2 Results of a general linear model analysis examining the changes in root and soil parameters in different soil layers along five various land use systems in Southeast Sulawesi, Indonesia

df (degrees of freedom), $\mathrm{L}_{\mathrm{rv}}$ (total root per volume of soil), $\mathrm{D}_{\mathrm{rv}}$ (dried root weight per volume of soil), SOC (soil organic carbon content), MWD (mean weight diameter, is measure of mean soil aggregate size)

Significant $p$ values are displayed in bold, $* * * p<0.001, * * p<0.01$ $* p<0.05, p<0.1$

\begin{tabular}{|c|c|c|c|}
\hline Response variables & Explanatory variables & df & $p$ value \\
\hline \multirow[t]{4}{*}{$\mathrm{L}_{\mathrm{rv}}\left(\mathrm{cm} \mathrm{cm}^{-3}\right)$} & Reps & 2 & 0.867 \\
\hline & LUS & 4 & $<.001 * * *$ \\
\hline & Soil Depth & 7 & $<.001 * * *$ \\
\hline & LUS*Soil Depth & 28 & 0.485 \\
\hline \multirow[t]{4}{*}{$\mathrm{D}_{\mathrm{rv}}\left(\mathrm{g} \mathrm{cm}^{-3}\right)$} & Reps & 2 & 0.947 \\
\hline & LUS & 4 & $<.001 * * *$ \\
\hline & Depth & 7 & $<.001 * * *$ \\
\hline & LUS*Soil Depth & 28 & $<.001 * * *$ \\
\hline \multirow[t]{4}{*}{$\operatorname{SOC}(\%)$} & Reps & 2 & 0.24 \\
\hline & LUS & 4 & 0.39 \\
\hline & Soil Layer & 2 & $<.001 * * *$ \\
\hline & LUS*Soil Layer & 8 & 0.976 \\
\hline \multirow[t]{4}{*}{ MWD (mm) } & Reps & 2 & 0.794 \\
\hline & LUS & 4 & $0.014 *$ \\
\hline & Soil Layer & 2 & $<.001 * * *$ \\
\hline & LUS*Soil Layer & 8 & 0.869 \\
\hline \multirow[t]{4}{*}{ Soil macropore $(\%)$} & Reps & 2 & 0.174 \\
\hline & LUS & 4 & $<.001 * * *$ \\
\hline & Soil Layer & 2 & $<.001 * * *$ \\
\hline & LUS*Soil Layer & 8 & $<.001 * * *$ \\
\hline \multirow[t]{2}{*}{ Soil infiltration $\left(\mathrm{cm}\right.$ hour $\left.^{-1}\right)$} & Reps & 2 & $0.001 * *$ \\
\hline & LUS & 4 & $0.002 * *$ \\
\hline
\end{tabular}

a

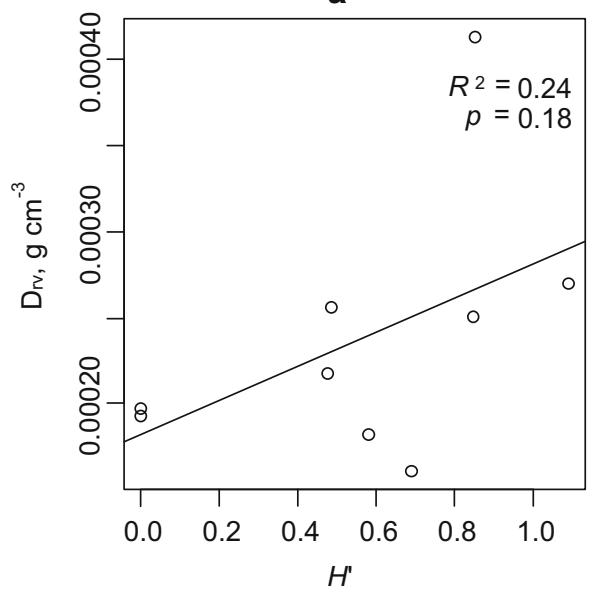

Fig. 5 Linear regression analysis between Shannon-Wiener diversity index ( $H^{\prime}$ ) from the same research plots by Sari et al. (2020) with $\mathrm{D}_{\mathrm{rv}}(\mathbf{a})$ and $\mathrm{L}_{\mathrm{rv}}(\mathbf{b})$ confirmed that practicing agroforestry in cocoa-based systems could increase root density

of shade tree diversity in complex agroforestry could produces 5.6 times higher macroporosity in deeper soil layer compared to other agricultural systems.
Furthermore, we observed a positive relation between SOC and MWD and macroporosity (Fig. 8c, d). 
Fig. 6 Soil organic carbon boxplot distribution across degraded forest (DF), complex agroforestry (CAF), simple agroforestry (SAF), cocoa monoculture (CM) and annual crop (CR) systems at three soil layers

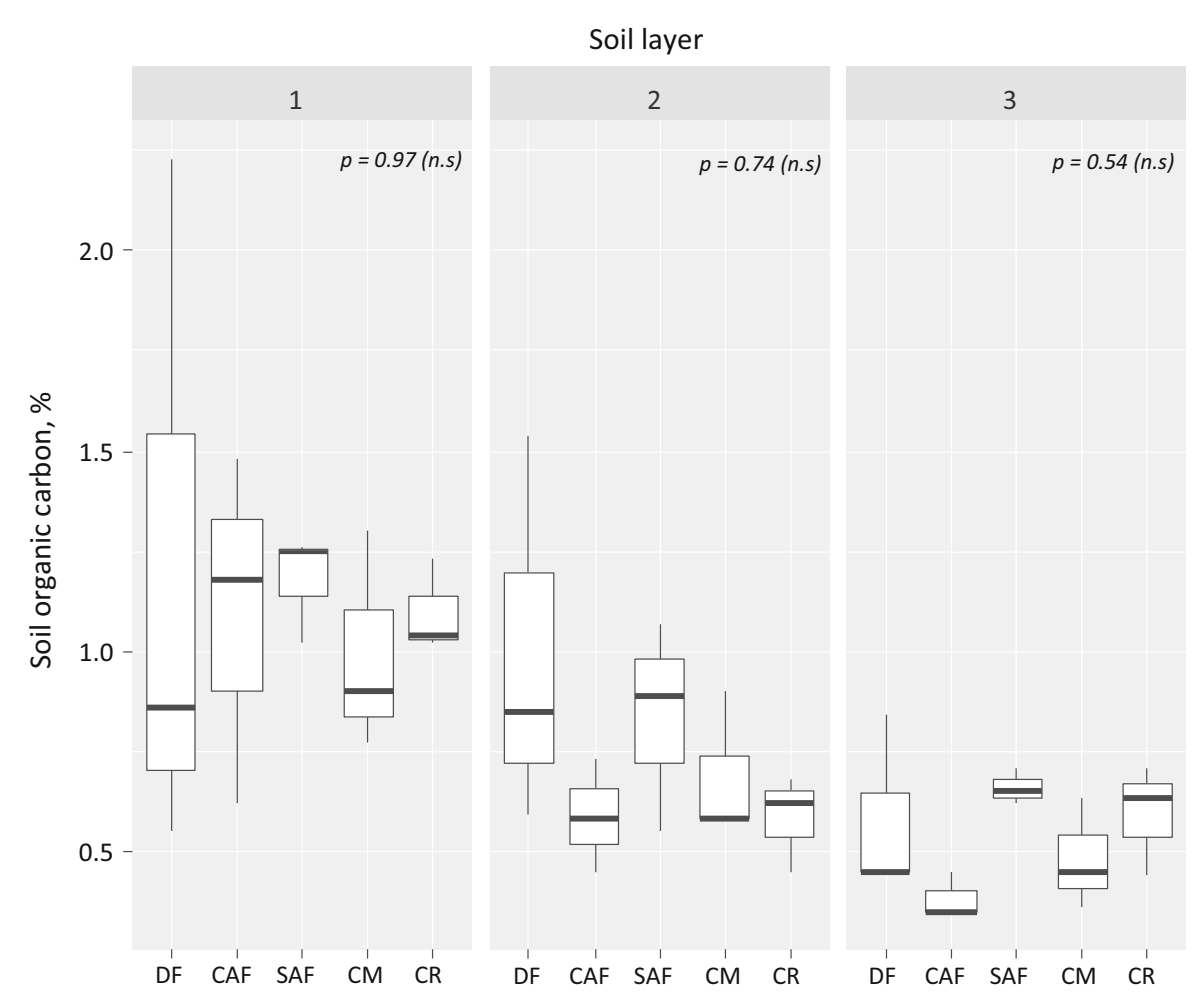

Soil infiltration and its correlation to soil aggregate stability and macroporosity

We created the infiltration curves using the soil infiltration field data after fitting the data in the Horton equation. The infiltration curves of each LUS show similar patterns (Fig. 9). The infiltration rates started to plummet from the initial time measurement and began to show a constant rate after $30 \mathrm{~min}$. The difference of LUS had a significant effect on steady state soil infiltration, with degraded forests having the highest rate (Fig. 10, Table 2). Across agricultural systems, however, the infiltration rate was not significantly different with average of $6 \mathrm{~cm} \mathrm{~h}^{-1}$. We found that integrating more tree species through complex agroforestry only slightly improved the soil infiltration. Linear regression analysis has found a significant positive impact of increasing macroporosity (Fig. 11b) to soil infiltration, but not with MWD (Fig. 11a).

\section{Discussion}

Incorporating shading trees through agroforestry increases fine root density

In our first hypotheses, we expected that the increase of tree diversity through agroforestry could improve the vertical distribution of fine root. Indeed, by combining tree diversity index from the same sampling sites from Sari et al. (2020) and current root data, we found that incorporating shade trees through complex agroforestry and simple agroforestry were positively associated to $\mathrm{L}_{\mathrm{rv}}\left(\mathrm{R}^{2}=0.37\right)$ and $\mathrm{D}_{\mathrm{rv}}$ $\left(\mathrm{R}^{2}=0.24\right)$ (Fig. 5a, b). This assertion supported by Rajab et al. (2018) which explained that the presence of shade trees in agroforestry systems resulted in higher stem densities and aboveground biomass which could increase root biomass over unshaded monocultures.

However, the low coefficients of determination in Fig. 5a, b indicated that higher tree diversity was not the sole influencing factor for higher root density. We assumed that high organic deposit at topsoil in agroforestry systems originating from aboveground sources (leaf litter and understorey) and belowground 
Fig. 7 Mean weight diameter boxplot distribution of soil aggregate (a) and surface connected macroporosity (b) across degraded forest (DF), complex agroforestry (CAF), simple agroforestry (SAF), cocoa monoculture (CM) and annual crop (CR) systems

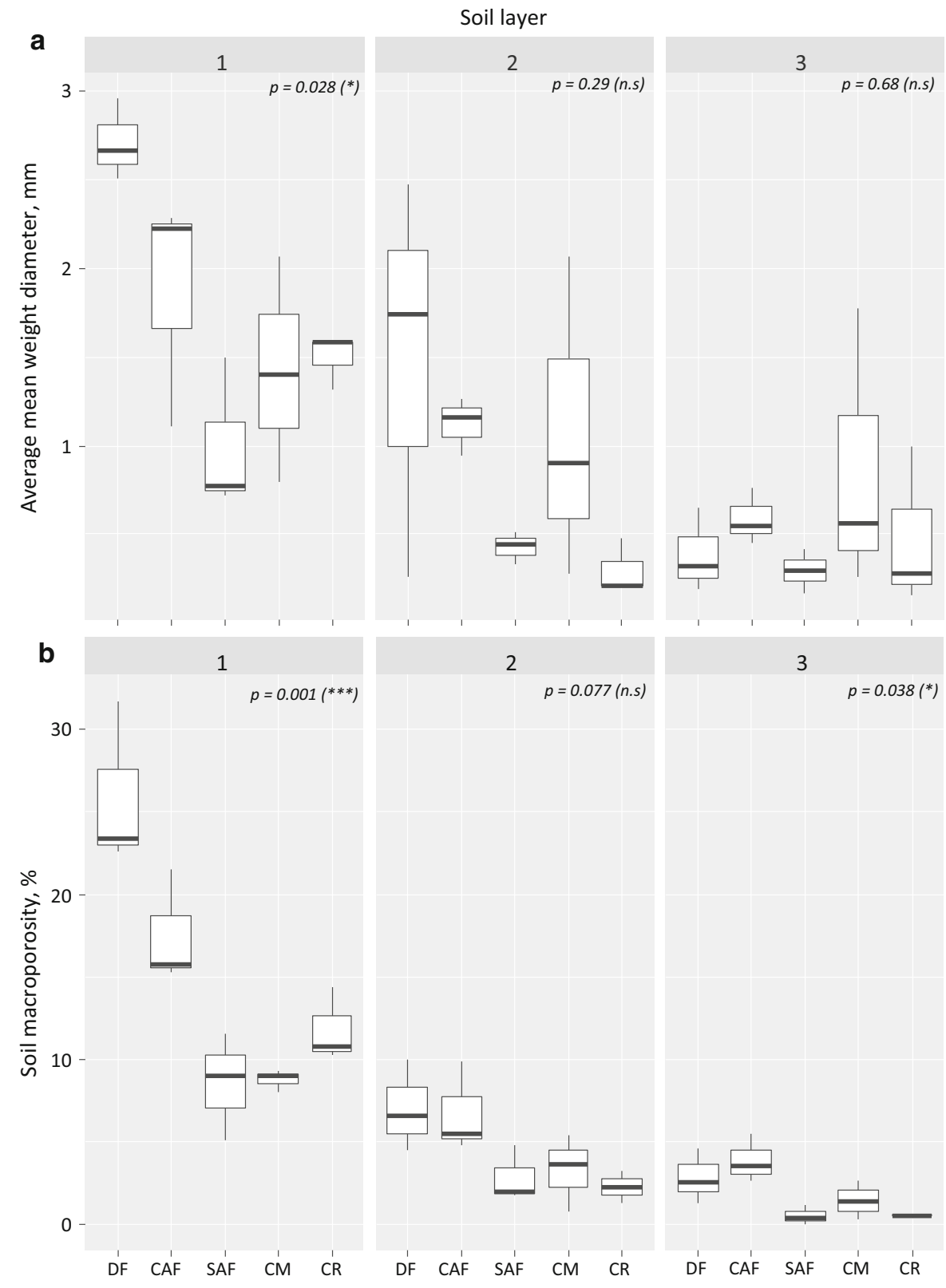

sources (root turnover and soil organism activity) could improve the nutrient availability after decomposition. The abundance of nutrients in the topsoil in mixed systems could trigger competition among trees for resources acquisition, and as a mitigation effort trees will localise the root growth as well as increase its rate resulting in higher $\mathrm{L}_{\mathrm{rv}}$ and $\mathrm{D}_{\mathrm{rv}}$. This might also explain the slight decreases gradient of root density on cocoa monoculture along with the soil depth as a complementarity form of these systems in acquiring limited nutrients at topsoil. Borden et al. (2019) found that cocoa fine root distribution in mixed systems with Entandrophragma angolense and Terminalia ivorensis was concentrated in shallow soils compared to cocoa monoculture. However, at the fine scale of individual roots it was not easy to separate competitive (resource depletion) and facilitative (organic deposition) effects in monospecific and mixed stands (Borden et al. 2019; Mommer et al. 2016). 

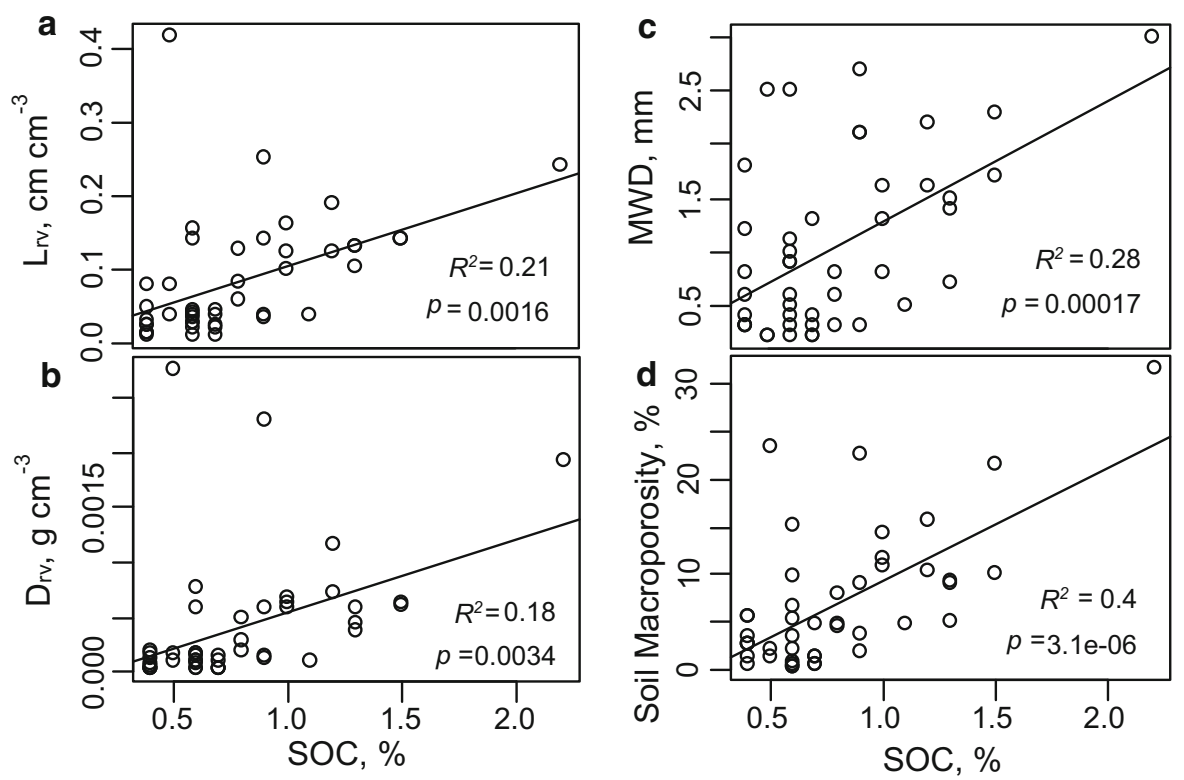

Fig. 8 Linear regression analysis between soil organic carbon and $\mathrm{L}_{\mathrm{rv}}(\mathbf{a}), \mathrm{D}_{\mathrm{rv}}(\mathbf{b}), \mathrm{MWD}(\mathbf{c})$ and soil macropore (d)

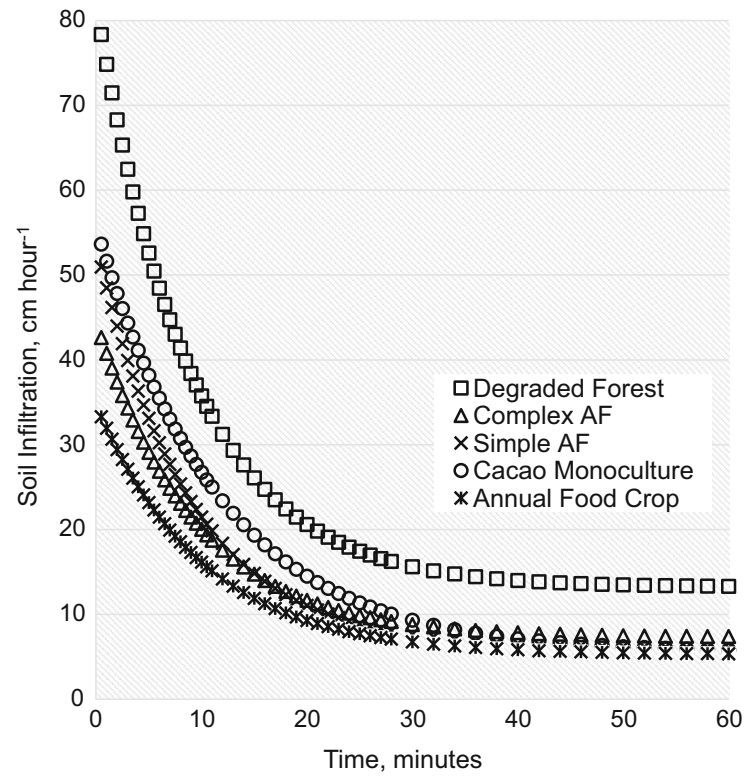

Fig. 9 Soil infiltration curve across degraded forest, complex agroforestry, simple agroforestry, cocoa monoculture and annual food crop systems. The infiltration curve derived from the average of field measurements data after fitted in Horton equation

On the other hand, the average of fine root density $\left(\mathrm{L}_{\mathrm{rv}}\right.$ and $\mathrm{D}_{\mathrm{rv}}$ ) produced by the annual crop system was not significantly different from that of cocoa-based systems which concentrated in the upper soil layers

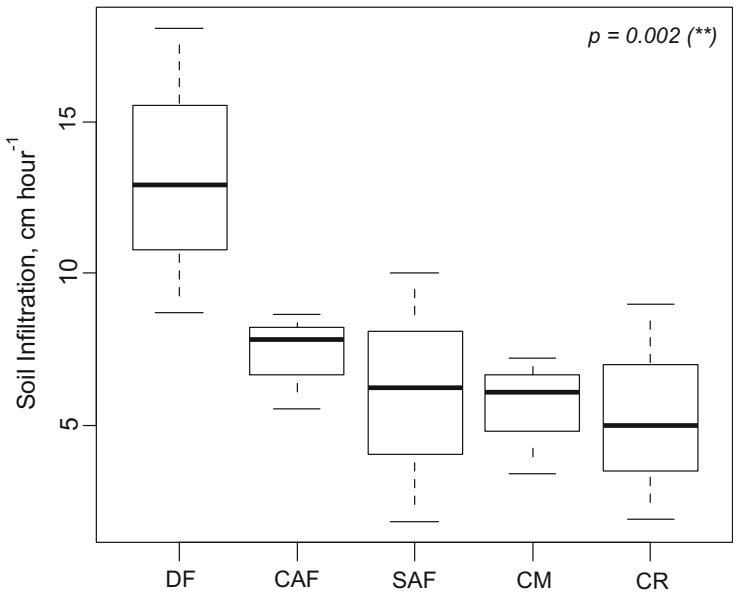

Fig. 10 Boxplot distribution of steady state infiltration across degraded forest (DF), complex agroforestry (CAF), simple agroforestry (SAF), cocoa monoculture (CM) and annual crop (CR) systems (9a) and linear regression analysis between soil macropore $(9 b)$ and mean weight diameter (9c) with soil infiltration

and decreases with soil depth. This condition was in line with research by Gao et al. (2010) which found that the fine root lengths of maize and soybean plants were mainly distributed in the $0-30 \mathrm{~cm}$ of the soil layer and continue to decrease with soil depth. However, this does not mean that the total root biomass produced was equal, as the root class observed in this study was 


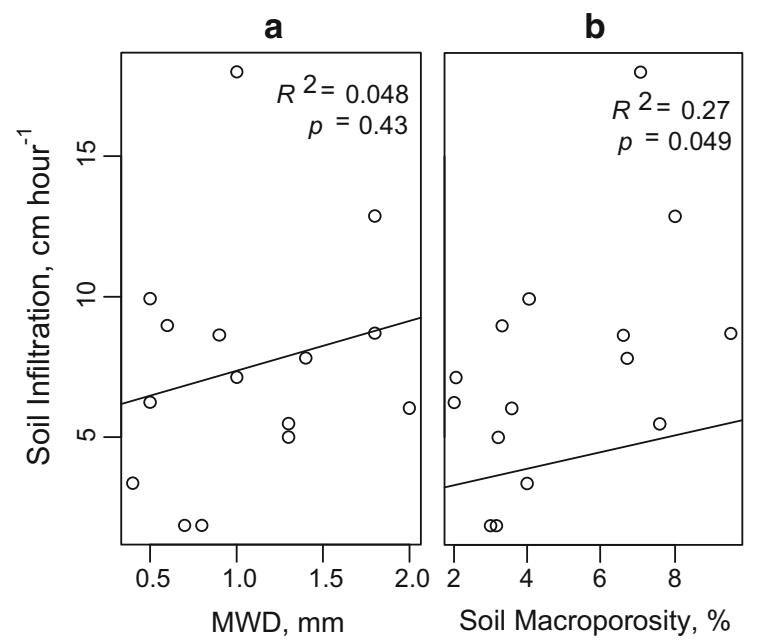

Fig. 11 Linear regression analysis between soil infiltration and MWD (a) and soil macroporosity (b)

only fine roots $(\mathrm{d}<2 \mathrm{~mm})$, whereas with trees large roots $(\mathrm{d}=2-5 \mathrm{~mm})$ and coarse root $(\mathrm{d}>5 \mathrm{~mm})$ were excluded.

Increasing fine root distribution positively correlated to soil organic carbon

Even though the increasing of shading trees in cocoa based system did not have a significant effect on soil organic carbon, as it was found in this research as well as in the study of Wartenberg et al. (2017), the increasing of fine root distribution alongside with tree diversity was positively correlated to soil organic carbon (Fig. 8a, b). The combination of cocoa with Gliricidia sepium in simple agroforestry were associated with a noticeable increases of soil organic carbon in deeper soil layer compared to other cocoa based systems. Similarly, the increasing of tree diversity (combinations of fruit and timber trees) in complex agroforestry slightly improved soil organic carbon at topsoil, but with no effect on deeper soil layers. This result was agreed with that by Rajab et al. (2018) which stated that the fine root turnover of the Gliricidia sepium shade trees in agroforestry system was high particularly in the deeper soil layers and significantly exceeded the turnover rate of cocoa trees. In contrast, the shade trees in the cocoa multi plot had an only slow fine root turnover, which was significantly less than that of the cocoa trees.
The total soil carbon concentration in monoculture cocoa was as high as that in other tree based systems. Even though the aboveground biomass from tree, as one of the primary sources of organic matter, was only $12 \%, 67 \%$ and $65 \%$ relative to degraded forests, complex agroforestry and simple agroforestry, respectively (Sari et al. 2020). Obalum et al. (2017) suggested fractionation of soil organic carbon could reveal more subtle differences in active fractions where total organic carbon is dominated by stable fractions. In the long run, the decline in total biomass production (aboveground and belowground) after forest conversion to agricultural systems may have the potential to reduce soil organic matter content. However, among the agriculture systems, the total biomass production of agroforestry (simple and complex) proved to be higher than monoculture systems so that over time soil organic carbon could incrementally increase or at least be maintained.

Higher soil organic carbon improves aggregate stability and soil macroporosity

The level of soil aggregate stability and macroporosity are related to root distribution and soil organic carbon content due to different land use management (third hypotheses). Our result showed that the different MWD across all land use systems was only significant in the topsoil with the ranges of $0.9 \mathrm{~mm}$ to $2.72 \mathrm{~mm}$. This numbers were relatively high compared to Wartenberg et al. (2017), where the range values were 0.9-1 mm for forests and 0.7 for cocoa-based systems. This might be caused by the different number of samples as well as the different land use ranges between the studies. However, both studies confirmed that MWD particularly at topsoil across cocoa-based system was lower compared to forests. This results were also supported by Le Bissonnais et al. (2018) which stated that soil aggregate stability was affected by land use changes only in surface layers where roots were most abundant and organic $\mathrm{C}$ inputs from leaf litterfall, and root litter were at the greatest amount.

The difference in land use system had a significant effect on soil macroporosity for the first and third soil layers, where average soil macroporosity in the topsoil was $80 \%$ higher compared to the deeper soil layer. The range of soil macroporosity in this research was $14.5 \%$ to $3.2 \%$, and it 2.6 times higher compared to Hairiah et al. (2006) that measured the topsoil macroporosity 
of forests and coffee based agroforestry in Lampung, Indonesia. The macroporosity at the agricultural system in Sumberjaya only reached $30 \%$ relative to the forests while in this study the difference in macroporosity was reached $50 \%$.

Practising simple agroforestry system did not significantly improve soil aggregate stability and macroporosity, even though it provided high soil organic carbon concentrations. The combination of trees with slow litter decomposition rate (which could help to protect the soil surface and create a better soil microclimate) and trees with the deep root system (which could create macroporosity when decomposed) in complex agroforestry was probably the best option to improve the soil physical condition (Hairiah et al. 2006).

Increasing root density, soil organic carbon, aggregate stability and soil macroporosity through agroforestry only slightly improves soil infiltration

Our measurement confirmed that different land use systems resulted in different infiltration rates. Degraded forests had soil infiltration rates two times faster compared to agricultural systems (Fig. 10). Dense, diverse and evenly distributed root system in degraded forest soil produced more recalcitrant root litter that slowly decomposed (Prieto et al. 2016), which increased the accumulation of soil organic carbon (Schmidt et al. 2011) leading to the formation and stabilization of soil transmission pores and higher infiltration (Vignozzi et al. 2019). The existence of shade trees in cocoa based agroforestry did only provide a slightly higher soil infiltration compared to cocoa monoculture. Similar result was found by Benegas et al. (2014), where well-managed coffee monoculture in Turrialba, Aquiares, Costa Rica provided the same function as agroforestry systems with respect to the formation of macroporosity and infiltration. However, research conducted in Copan River, Honduras (in the same publication) concluded that the existence of trees in agroforestry systems was positively correlated to macroporosity, preferential flow and infiltrability. Another factor possibly responsible for lower soil infiltration rates in agriculture systems might be related to the existence of surface crusting in agriculture systems due to weak soil aggregate stability (Gucci et al. 2012) which merits further investigation.
The slight improvement of soil quality and infiltration provided by cocoa agroforestry systems compared to monoculture might be correlate to the plot age after conversion to cocoa based systems. The early stage of this cocoa-based systems (9-14 years old cocoa) in this research were unable to restore the soil quality equal to the condition of degraded forests. The recovery of soil quality in agriculture systems, indeed, is a slow process. Several studies on management changes found that the loss of soil organic carbon was faster than soil organic carbon restoration (asymmetric response), due to the differences in organic matter input between restoration and degradation managements (Jensen et al. 2020). A study by Dawoe et al. (2014) revealed that soil quality deteriorated significantly in 3 year old cocoa systems, but only started to improve in 15 and 30 year old cocoa systems. Based on the positive trend showed on Fig. 10, however, the application of complex agroforestry, with time, potentially could provide a faster soil infiltration compared to other agriculture systems. Further study should investigate the long-term effect of agroforestry practices on soil quality, environmental services and land productivity.

\section{Conclusions}

Compared to simple agroforestry and cocoa monoculture, integrating a diverse combination of tree species in complex cocoa-based agroforestry systems significantly improved root density in the topsoil layer, even though only half of that in degraded forests. Practicing simple agroforestry significantly increased the soil organic carbon, particularly in deeper soil layer, whereas complex agroforestry only marginally improved soil organic carbon at topsoil compared to monoculture cocoa. Soil aggregate stability in degraded forests was higher compared to annual crop fields and simple agroforestry; while in complex agroforestry, soil aggregate stability in topsoil was within the confidence interval of measurement in degraded forests. Our study also highlighted that complex agroforestry recovered soil macroporosity better compared to other agricultural systems and impressively equal to degraded forests, particularly in the subsoil. Hence, complex agroforestry had slightly higher infiltration compared to other agricultural 
systems, even though still unable to achieve the soil infiltration rates of degraded forests.

Acknowledgements This research has been funded by the Canadian International Development Agency (CIDA) through the AgFor Southeast Sulawesi Project (Contribution Arrangement No. 7056890), under the coordination of the World Agroforestry Centre (ICRAF)-Southeast Asia. Discussions with the colleagues in the Southeast Sulawesi during the fieldwork and researchers on Scenario Analysis for Management of Agroforest Program (WCU-SAMA-2019) provided by Brawijaya University during the writing process have significant contributions to this research and publication. We acknowledge comments from two anonymous reviewers. Many thanks to the farmers in the Lawonua, Wonuahoa and Asinua Jaya for the kind help and warm family welcome. We also would like to thank Indonesia Endowment Fund for Education (LPDP) from the Ministry of Finance, the Republic of Indonesia for supporting this study.

Author contributions All authors contributed to the study conception and design. Material preparation, data collection and analysis were performed by Danny Dwi Saputra and Rika Ratna Sari. The first draft of the manuscript was written by Danny Dwi Saputra, all authors commented on previous versions of the manuscript and approved the final manuscript.

\section{Compliance with ethical standards}

Conflicts of interest The authors declare no conflict of interest.

Open Access This article is licensed under a Creative Commons Attribution 4.0 International License, which permits use, sharing, adaptation, distribution and reproduction in any medium or format, as long as you give appropriate credit to the original author(s) and the source, provide a link to the Creative Commons licence, and indicate if changes were made. The images or other third party material in this article are included in the article's Creative Commons licence, unless indicated otherwise in a credit line to the material. If material is not included in the article's Creative Commons licence and your intended use is not permitted by statutory regulation or exceeds the permitted use, you will need to obtain permission directly from the copyright holder. To view a copy of this licence, visit http://creativecommons.org/licenses/by/4.0/.

\section{References}

Anderson J, Ingram J (1994) Tropical soil biology and fertility: a handbook of methods. Soil Sci 157:265

Arévalo-Hernández CO, da Conceição Pinto F, de Souza Júnior JO, de Queiroz Paiva A, Baligar VC (2017) Variability and correlation of physical attributes of soils cultivated with cacao trees in two climate zones in Southern Bahia. Brazil Agrofor Syst 93:793-802. https://doi.org/10.1007/s10457017-0176-4
Barreto PAB et al (2010) Distribution of oxidizable organic C fractions in soils under cacao agroforestry systems in Southern Bahia. Brazil Agrofor Syst 81:213-220. https:// doi.org/10.1007/s10457-010-9300-4

Benegas L, Ilstedt U, Roupsard O, Jones J, Malmer A (2014) Effects of trees on infiltrability and preferential flow in two contrasting agroecosystems in Central America. Agric Ecosyst Environ 183:185-196. https://doi.org/10.1016/j. agee.2013.10.027

Borden KA, Thomas SC, Isaac ME (2019) Variation in fine root traits reveals nutrient-specific acquisition strategies in agroforestry systems. Plant Soil. https://doi.org/10.1007/ s11104-019-04003-2

Carrizo ME, Alesso CA, Cosentino D, Imhoff S (2015) Aggregation agents and structural stability in soils with different texture and organic carbon contents. Sci Agric 72:75-82. https://doi.org/10.1590/0103-9016-2014-0026

Chae HM, Choi SH, Lee SH, Cha S, Yang KC, Shim JK (2019) Effect of litter quality on needle decomposition for four pine species in Korea. Forests. https://doi.org/10.3390/ f10050371

Chaplot V, Jewitt G, Lorentz S (2011) Predicting plot-scale water infiltration using the correlation between soil apparent electrical resistivity and various soil properties. Phys Chem Earth Parts A/B/C 36:1033-1042. https://doi. org/10.1016/j.pce.2011.08.017

Dawoe EK, Quashie-Sam JS, Oppong SK (2014) Effect of landuse conversion from forest to cocoa agroforest on soil characteristics and quality of a Ferric Lixisol in lowland humid Ghana. Agrofor Syst 88:87-99. https://doi.org/10. 1007/s10457-013-9658-1

FAO (2017) Production/Yield Quantities of Cacao Beans 2000-2014. http://www.fao.org/faostat/en/\#data/QC/ visualize

FAO-UNESCO (1979) Soil map of the world vol IX. UNESCO, Place de Fontenoy, Paris. http://www.fao.org/3/as353e/ as353e.pdf

Gao Y, Duan A, Qiu X, Liu Z, Sun J, Zhang J, Wang H (2010) Distribution of roots and root length density in a maize/soybean strip intercropping system. Agric Water Manag 98:199-212. https://doi.org/10.1016/j.agwat.2010. 08.021

Gucci R et al (2012) Changes of soil properties and tree performance induced by soil management in a high-density olive orchard. Eur J Agron 41:18-27. https://doi.org/10. 1016/j.eja.2012.03.002

Hairiah K, Sulistyani H, Suprayogo D, Widianto, Purnomosidhi P, Widodo RH, Van Noordwijk M (2006) Litter layer residence time in forest and coffee agroforestry systems in Sumberjaya, West Lampung. For Ecol Manag 224: 45-57. doi:10.1016/j.foreco.2005.12.007

Hoffmann WA (2003) Regional feedbacks among fire, climate, and tropical deforestation. J Geophys Res 5:2. https://doi. org/10.1029/2003JD003494

Jensen JL, Schjønning P, Watts CW, Christensen BT, Obour PB, Munkholm LJ (2020) Soil degradation and recovery: changes in organic matter fractions and structural stability. Geoderma 364:114181. https://doi.org/10.1016/j. geoderma.2020.114181 
Lal R (2015) Restoring soil quality to mitigate soil degradation. Sustainability 7:5875-5895. https://doi.org/10.3390/ su7055875

Le Bissonnais $\mathrm{Y}$ et al (2018) Soil aggregate stability in Mediterranean and tropical agro-ecosystems: effect of plant roots and soil characteristics. Plant Soil 424:303-317. https://doi.org/10.1007/s11104-017-3423-6

Mahapatra S, Jha MK, Biswal S, Senapati D (2020) Assessing variability of infiltration characteristics and reliability of infiltration models in a tropical sub-humid region of india. Sci Rep 10:1515. https://doi.org/10.1038/s41598-02058333-8

Martinez-Salgado, Gutiérrez-Romero V, Jannsens M, OrtegaBlu R (2010) Biological soil quality indicators: a review. In: Mendez-Vilas A (ed) Current research, technology and education topics in applied microbiology and microbial biotechnology, FORMATEX, pp 319-328. https://www. researchgate.net/publication/285738755_Biological_soil_ quality_indicators_a_review

Mommer L, Kirkegaard J, van Ruijven J (2016) Root-Root Interactions: towards a rhizosphere framework. Trends Plant Sci 21:209-217. https://doi.org/10.1016/j.tplants. 2016.01.009

Neilson J (2007) Global markets, farmers and the state: sustaining profits in the Indonesian cocoa sector. Bull Indones Econ Stud 43:227-250. https://doi.org/10.1080/ 00074910701408073

Norgrove L, Beck J (2016) Biodiversity function and resilience in tropical agroforestry systems including shifting cultivation. Curr For Rep 2:62-80. https://doi.org/10.1007/ s40725-016-0032-1

Obalum SE, Chibuike GU, Peth S, Ouyang Y (2017) Soil organic matter as sole indicator of soil degradation. Environ Monit Assess 189:176. https://doi.org/10.1007/ s10661-017-5881-y

Obeng EA, Aguilar FX (2015) Marginal effects on biodiversity, carbon sequestration and nutrient cycling of transitions from tropical forests to cacao farming systems. Agrofor Syst 89:19-35. https://doi.org/10.1007/s10457-014-97399

Ordonez JC, Luedeling E, Kindt R, Tata HL, Harja D, Jamnadass R, van Noordwijk M (2014) Constraints and opportunities for tree diversity management along the forest transition curve to achieve multifunctional agriculture. Curr Opin Environ Sustain 6:54-60. https://doi.org/ 10.1016/j.cosust.2013.10.009

Pinho RC, Miller RP, Alfaia SS (2012) Agroforestry and the Improvement of Soil Fertility: a View from Amazonia. Appl Environ Soil Sci 2012:1-11. https://doi.org/10.1155/ 2012/616383

Prieto I, Stokes A, Roumet C (2016) Root functional parameters predict fine root decomposability at the community level. J Ecol 104:725-733. https://doi.org/10.1111/1365-2745. 12537

Rajab YA, Hölscher D, Leuschner C, Barus H, Tjoa A, Hertel D (2018) Effects of shade tree cover and diversity on root system structure and dynamics in cacao agroforests: the role of root competition and space partitioning. Plant Soil 422:349-369. https://doi.org/10.1007/s11104-017-3456-x
Rice EC, Grismer ME (2010) Dry-season soil water repellency affects Tahoe Basin infiltration rates. Calif Agric 64:141-148. https://doi.org/10.3733/ca.v064n03p141

Sahin H, Anderson SH, Udawatta RP (2016) Water infiltration and soil water content in claypan soils influenced by agroforestry and grass buffers compared to row crop management. Agrofor Syst 90:839-860. https://doi.org/10. 1007/s10457-016-9899-x

Saito T, Yasuda H, Suganuma H, Inosako K, Abe Y, Kojima T (2016) Predicting soil infiltration and horizon thickness for a large-scale water balance model in an arid environment. Water 8:96. https://doi.org/10.3390/w8030096

Sanchez PA (2019) Properties and management of soils in the tropics, 2nd edn. Cambridge University Press, Cambridge. https://doi.org/10.1017/9781316809785

Sari RR, Saputra DD, Hairiah K, Rozendaal MAD, Roshetko MJ, van Noordwijk M (2020) gendered species preferences link tree diversity and carbon stocks in cacao agroforest in Southeast Sulawesi. Indonesia Land. https://doi.org/10. 3390/land9040108

Schmidt MWI et al (2011) Persistence of soil organic matter as an ecosystem property. Nature 478:49-56. https://doi.org/ 10.1038/nature 10386

Schoene D, Killmann W, Loepke H, LoycheWilkie M (2007) Definitional issues related to reducing emissions from deforestation in developing countries. In: Forests and climate change working paper (FAO). http://wwwfaoorg/3/ j9345e/j9345e00htm

Schroth G, Lehmann J, Rodrigues MRL, Barros E, Macêdo JLV (2001) Plant-soil interactions in multistrata agroforestry in the humid tropics. Agrofor Syst 53:85-102. https://doi.org/ 10.1023/A:1013360000633

Suprayogo D, Widianto, Zauhara Aini Z, Purnomosidi P, Khasanah N, Widodo RH, Kusuma Z (2004) Degradasi sifat fisik tanah sebagai akibat alihguna lahan hutan menjadi sistem kopi monokultur: Kajian perubahan makroporositas tanah. Agrivita 26:60-68

Tscharntke T et al (2011) Multifunctional shade-tree management in tropical agroforestry landscapes: a review. J Appl Ecol 48:619-629. https://doi.org/10.1111/j.1365-2664. 2010.01939. $\mathrm{x}$

Vaast P, Somarriba E (2014) Trade-offs between crop intensification and ecosystem services: the role of agroforestry in cocoa cultivation. Agrofor Syst 88:947-956. https://doi. org/10.1007/s10457-014-9762-x

van Noordwijk M et al. (2019) Tree diversity as basis of agroforestry. In: van Noordwijk M (ed) Sustainable development through trees on farms: agroforestry in its fifth decade. In: World Agroforestry Centre (ICRAF) Southeast Asia Regional Program, Bogor, Indonesia, pp 17-44. http://www.worldagroforestry.org/book-chapter/treediversity-basis-agroforestry

van Noordwijk M, Cerri C, Woomer PL, Nugroho K, Bernoux M (1997) Soil carbon dynamics in the humid tropical forest zone. Geoderma 79:187-225. https://doi.org/10.1016/ S0016-7061(97)00042-6

van Noordwijk M, Lawson G, Hairiah K, Wilson J (2015) Chapter 8: root distribution of trees and crops: competition and/or complementarity. In: Ong CK, Black CR, Wilson J (eds). CAB International, Wallingford, UK, pp 221-257. https://www.researchgate.net/publication/292979267_ 
Chapter_292979268_Root_distribution_of_trees_and_ crops_competition_andor_complementarity

Vignozzi $\bar{N}$ et al (2019) Soil ecosystem functions in a highdensity olive orchard managed by different soil conservation practices. Appl Soil Ecol 134:64-76. https://doi.org/ 10.1016/j.apsoil.2018.10.014

Wartenberg AC, Blaser WJ, Gattinger A, Roshetko JM, Van Noordwijk M, Six J (2017) Does shade tree diversity increase soil fertility in cocoa plantations? Agric Ecosyst Environ 248:190-199. https://doi.org/10.1016/j.agee. 2017.07.033
Zamora D, Udawatta RP (2016) Agroforestry as a catalyst for on-farm conservation and diversification. Agrofor Syst 90:711-714. https://doi.org/10.1007/s10457-016-0013-1

Publisher's Note Springer Nature remains neutral with regard to jurisdictional claims in published maps and institutional affiliations. 